
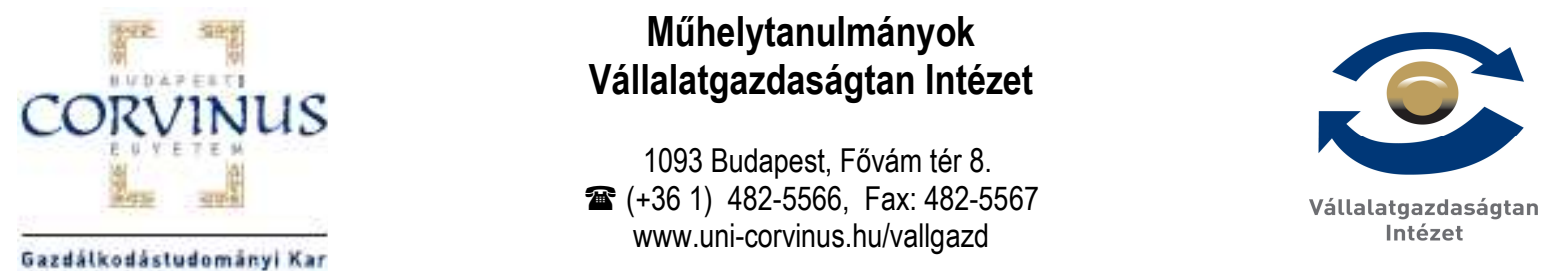

\title{
A Dynamic Input-Output Model with Renewable Resources
}

\author{
Imre Dobos \\ Péter Tallos \\ 137. sz. Múhelytanulmány \\ HU ISSN 1786-3031
}

2011. április

Budapesti Corvinus Egyetem

Vállalatgazdaságtan Intézet

Fővám tér 8.

H-1093 Budapest

Hungary 


\title{
A Dynamic Input-Output Model with Renewable Resources
}

\author{
Imre Dobos ${ }^{1}$ \\ Péter Tallos ${ }^{2}$ \\ ${ }^{1}$ Corvinus University of Budapest, Institute of Business Economics, H-1093 Budapest, Fővám tér 8., Hungary, \\ imre.dobos@uni-corvinus.hu \\ 2 Corvinus University of Budapest, Department of Mathematics, H-1093 Budapest, Fővám tér 13-15., Hungary, \\ tallos@uni-corvinus.hu
}

\begin{abstract}
Absztrakt.
A dolgozat a dinamikus input-output modell egy általánosítását tárgyalja. A sztenderd dinamikus Leontief-modellt terjesztjük ki arra az esetre, amikor a megújuló erőforrások egyenleteit is a modellhez csatoljuk. A megújuló eröforrások készletei növekednek a regenerációs rátával, amit csökkent a felhasználás üteme. Ebben a dolgozatban az új modell irányíthatóságát vizsgáljuk, a fogyasztási rátát tekintve irányítási változónak. Az egyensúlyi arányos pályát vizsgálva arra keresünk választ, hogy milyen növekedési ütemet képes elérni a gazdaság anélkül, hogy kimerítené a megújuló erőforrásokat. A megoldásban az irányításelmélet és a klasszikus lineáris algebra eredményeit használjuk fel.
\end{abstract}

Kulcsszavak: Dinamikus rendszerek, Sajátérték feladat, Irányításelmélet, Környezeti menedzsment

\begin{abstract}
.
The paper studies a generalisation of the dynamic Leontief input-output model. The standard dynamic Leontief model will be extended with the balance equation of renewable resources. The renewable stocks will increase regenerating and decrease exploiting primary natural resources. In this study the controllability of this extended model is examined by taking the consumption as the control parameter. Assuming balanced growth for both consumption and production, we investigate the exhaustion of renewable resources in dependence on the balanced growth rate and on the rate of natural regeneration. In doing so, classic results from control theory and on eigenvalue problems in linear algebra are applied.
\end{abstract}

Keywords: Dynamical Systems, Eigenvalue Problem, Control Theory, Environmental Management 


\title{
A Dynamic Input-Output Model with Renewable Resources
}

\author{
Imre Dobos* and Peter Tallos ${ }^{\dagger}$
}

\begin{abstract}
The paper studies a generalisation of the dynamic Leontief inputoutput model. The standard dynamic Leontief model will be extended with the balance equation of renewable resources. The renewable stocks will increase regenerating and decrease exploiting primary natural resources. In this study the controllability of this extended model is examined by taking the consumption as the control parameter. Assuming balanced growth for both consumption and production, we investigate the exhaustion of renewable resources in dependence on the balanced growth rate and on the rate of natural regeneration. In doing so, classic results from control theory and on eigenvalue problems in linear algebra are applied.
\end{abstract}

Keywords: Dynamical Systems, Eigenvalue Problem, Control Theory, Environmental Management

\section{Introduction}

Solving environmental problems such as the exhaustion of natural resources urges a thorough analysis of the interaction between the development of the economy and the natural environment. In this paper we present an environmental impact study focusing on the interdependence of the economic activities and the associated flow of renewable resources. Despite its known simplifications, input-output analysis is a useful instrument to study strategic directions of economic development, extending dynamic intersectoral links also to the interaction between the sectors of economy and the natural environment. Such an analysis is important for the development of state regulation programs, which are an integral part of environmental-economic policy for any developed market system (Field, [8]).

\footnotetext{
*Institute of Business Economics, Corvinus University of Budapest, Hungary, imre.dobos@uni-corvinus.hu, (Corresponding author)

${ }^{\dagger}$ Department of Mathematics, Corvinus University of Budapest, Hungary
} 
In the economic literature renewable resources are often examined. The first known paper on this field was published by Hotelling in year 1931. This first applications analysis investigate the fishery processes (Clark, [3]). These types of model use logistic differential equation to describe the motion of the problem. The models are then characterized by profit function to maximize the present value. A second direction analyzes a growth model in general equilibrium context. In these models the discounted utility function of the economy is maximized (Ayong Le Kama, [2], Wirl, [14]). Similar models are investigated by Elíasson and Turnovsky [7] who look for macroeconomic equilibrium and a balanced growth. The use of renewable resources raises the question of sustainability of the resource utilization policy (Valente, [13], Li and Löfgren, [11]). All of these models apply continuous time economic models.

In this study, we consider the well-known dynamic Leontief input-output model augmented with the balance equation of regenerative natural resources (Leontief, [10]). One of the questions arising in this ecological input-output model is whether this dynamic model is controllable if consumption is taken as the control parameter? In other words, can the use of the natural resources be influenced by controlling the consumption in the economy? The other question we intend to answer is how the rate of regeneration of a renewable resource influences growth rate for both consumption and production, if an environmental regulation agency does not want to fully exhaust a renewable resource.

This paper is a natural extension of our former results for renewable resources in the case of a singular matrix of capital coefficients (see Dobos and Floriska [5], [6]).

For our investigations we use classical results from control theory and eigenvalue problems in linear algebra. The next section presents the basic equation system of the augmented dynamic Leontief system. The following sections examine the controllability and the balanced growth path of the system respectively. Finally, we illustrate our results for a simple numerical example.

\section{The Dynamic Leontief Model}

Our model is based on the equations of the dynamic multi-sector input-output model well known in the literature (Leontief, [10]). We extend this model with the balance equation of renewable resources in order to analyse the linkage between the economy and the environment.

Suppose that there are $n$ economic industries, each industry producing a single commodity and $m$ primary resources used by the sectors of productions. (Each industry may use more resources and let us suppose that $m<n$ ). The input-output balance of the entire economy can be described by the equations for goods and resources. The equation for goods describes the balance between the total output of goods and the sum of total inputs of goods and the consumed goods. 
Let us consider

$$
x(t)=A x(t)+B \dot{x}(t)+c(t)
$$

where $x(t)$ is the nonnegative $n$-dimensional vector of gross industrial outputs in year $t ; c(t)$ is the $n$-dimensional vector of final consumption demands for commodities in year $t ; A$ is the $n \times n$ matrix of input coefficients, showing the input of goods that are required to produce one unit of a product; and $B$ is the $n \times n$ matrix of capital coefficients, where the element $b_{i j}$ is the capital requirement of good $i$ necessary for the increase of one unit of output in sector $j$. It is assumed that the matrix of capital coefficients is singular, i.e. it is not invertible.

The equation for resources describes the relation between the stocks of renewable resources in two subsequent years, taking the regeneration and exploitation in a given year into account.

Now consider

$$
\dot{N}(t)=<g>N(t)-E x(t)
$$

where $N(t)$ is the nonnegative $m$-dimensional vector of renewable resources in year $t, g$ is the $m$-dimensional vector of rates of natural regeneration of natural resources and $\langle g\rangle$ is an $m$-dimensional diagonal matrix, with the rates of regeneration of the resources in the diagonal. $E$ is the $m \times n$ matrix of input coefficients of resources, where the element $E_{i j}$ is the requirement of resource $i$ to produce one unit of output in sector $j$.

Throughout this paper we assume that:

- the matrices $A, B$ and $E$ are nonnegative,

- the matrix $A$ is productive and its Leontief inverse $\left(I_{n}-A\right)^{-1}$ is nonnegative, where $I_{n}$ is the $n \times n$ identity matrix,

- $B$ is singular,

- $c(t)$ is a nonnegative vector.

The two equations above can be written in explicit vector form:

$$
\left[\begin{array}{cc}
B & 0 \\
0 & I_{m}
\end{array}\right] \cdot\left[\begin{array}{c}
\dot{x}(t) \\
\dot{N}(t)
\end{array}\right]=\left[\begin{array}{cc}
I_{n}-A & 0 \\
-E & <g>
\end{array}\right] \cdot\left[\begin{array}{c}
x(t) \\
N(t)
\end{array}\right]-\left[\begin{array}{c}
I_{n} \\
0
\end{array}\right] \cdot c(t)
$$

and because of the singularity of the $2 \times 2$ matrix on the right-hand side, controllability of system (3) cannot be analyzed by using the classical Kalman's condition (see Aoki, [1]). We must solve this system explicitely to express the solution of the linear diffential equation system. This system is solvable because matrices of system (3) build regular matrix pencils (Gantmacher, [9]). The regularity of the matrix pencils can be proven easily:

$$
\lambda\left[\begin{array}{cc}
B & 0 \\
0 & I_{m}
\end{array}\right]-\left[\begin{array}{cc}
I_{n}-A & 0 \\
-E & <g>
\end{array}\right]=\left[\begin{array}{cc}
\lambda B-\left(I_{n}-A\right) & 0 \\
E & \lambda I_{m}-<g>
\end{array}\right]
$$


If $\lambda=0$ in the last expression then the matrix on the right-hand side is invertible, and

$$
\left[\begin{array}{cc}
I_{n}-A & 0 \\
-E & <g>
\end{array}\right]^{-1}=\left[\begin{array}{cc}
\left(I_{n}-A\right)^{-1} & 0 \\
\langle g\rangle^{-1} E\left(I_{n}-A\right)^{-1} & \langle g\rangle^{-1}
\end{array}\right]
$$

This means that model (3) is solvable and there exists an explicit solution (Gantmacher, [9]).

\section{Controllability of the Model}

The controllability of a system means that the system can be steered from any given initial state to any other state in a finite time period by means of a suitable choice of the control function (Aoki [1]). Applying Kalman's theorem (Aoki [1]) we get that system (3) is controllable if and only if the rank condition is satisfied. Note that $\left[\bar{B}, \overline{A B}, \ldots, \bar{A}^{m+n-1} \bar{B}\right]$ is an $(n+m) \times(n+m)$ matrix.

Theorem 1 The system (3) is controllable if and only if rank $E=m$.

Proof. Consider the time interval $[0, T]$ and a solution $x$ to (1) with $x(0)=x_{0}$ and $x(T)=x_{T}$. Consider the $m \times m$ matrix $<g>$ and denote by $\Phi$ the matrix solution to the homogeneous linear system

$$
\dot{N}(t)=<g>N(t)
$$

Let $E$ be a real $m \times n$ matrix with rank $m$ and consider the following subset of all $\mathbb{R}^{n}$-valued continuously differentiable functions on the interval $[0, T]$

$$
C_{0, T}=\left\{x \in C^{1}[0, T]: x(0)=x_{0}, x(T)=x_{T}\right\}
$$

Define the linear mapping $\Lambda: C^{1} \rightarrow \mathbb{R}^{m}$ by

$$
\Lambda x=\int_{0}^{T} \Phi(t)^{-1} E x(t) d t
$$

Under the above conditions the system (3) is controllable, i.e.

$$
\Lambda\left(C_{0, T}\right)=\mathbb{R}^{m}
$$

if and only if the matrix $E$ is of full rank.

The necessity of the condition is obvious. To prove the sufficiency, let $v \in \mathbb{R}^{m}$ be given arbitrarily. We have to find an $x \in C_{0, T}$ with

$$
v=\Lambda x=\int_{0}^{T} \Phi(t)^{-1} E x(t) d t
$$


Introduce the notations $y_{0}=E x_{0}$ and $y_{T}=E x_{T}$. Clearly, if we can find a continuously differentiable function $y:[0, T] \rightarrow \mathbb{R}^{m}$ with $y(0)=y_{0}$ and $y(T)=y_{T}$ further with

$$
v=\int_{0}^{T} y(t) d t
$$

then the function defined by

$$
E x(t)=\Phi(t) y(t)
$$

fulfills the criteria of the theorem.

In order to find an $y$ with this property, pick any continuously differentiable function $\hat{y}$ on $[0, T]$ with $\hat{y}(0)=y_{0}$ and $\hat{y}(T)=y_{T}$. Suppose

$$
\int_{0}^{T} \hat{y}(t) d t=w \in \mathbb{R}^{m}
$$

Let $\alpha$ and $\beta$ be undefined real parameters and consider the family of continuously differentiable functions

$$
y_{\alpha, \beta}(t)=\hat{y}(t)+\alpha t(T-t) v+\beta t(T-t) w
$$

for every $t$ in $[0, T]$. It can be verified easily that $y_{\alpha, \beta}$ still satisfies the boundary conditions, i.e. $y_{\alpha, \beta}(0)=y_{0}$ and $y_{\alpha, \beta}(T)=y_{T}$ for every real $\alpha$ and $\beta$. Moreover, a straightforward calculation shows that for appropriate values of $\alpha$ and $\beta$ we have

$$
\int_{0}^{T} y_{\alpha, \beta}(t) d t=v
$$

For those $\alpha$ and $\beta$ introduce

$$
y(t)=y_{\alpha, \beta}(t)=\hat{y}(t)+\alpha t(T-t) v+\beta t(T-t) w
$$

and consider the equation

$$
\operatorname{Ex}(t)=\Phi(t) y(t)
$$

on the interval $[0, T]$. On the one hand the vector space $\mathbb{R}^{m}$ can be given as the direct sum of the orthogonal subspaces

$$
\mathbb{R}^{m}=\operatorname{ker} E \oplus \operatorname{im} E^{*}
$$

where $E^{*}$ stands for the adjoint of the matrix $E$, on the other hand $E$ creates an isomorphism between the $m$-dimensional spaces $\mathbb{R}^{m}$ and im $E^{*}$. Therefore, for any $y$ there exists a continuously differentiable function $x$ on $[0, T]$ with $x(0)=x_{0}$ and $x(T)=x_{T}$ that is a solution to $(3)$.

Remark. The controllability of system (3) could also be proved by the classical matrix conditions for singular systems (cf. Dai, [4]). The reason why we have chosen this explicit approach is to demonstrate the special structure of 
the economic-ecological system. The linear system (3) consists of two types of differential equations. The first (1) points out the economic system, while equations (2) represent the ecological system. In other words, the economic model influences the ecological system. Our proof relies on this phenomenon and captures some insight into the structure of the economic-ecological nature of the model. Here we briefly sketch how to exploit the matrix conditions by Dai, [4]. The condition possesses the form

$$
\operatorname{rank}\left\{s \cdot\left[\begin{array}{cc}
B & 0 \\
0 & I_{m}
\end{array}\right]-\left[\begin{array}{cc}
I_{n}-A & 0 \\
-E & \langle g\rangle
\end{array}\right] ;\left[\begin{array}{c}
-I_{n} \\
0
\end{array}\right]\right\}=n+m
$$

for all scalars $s \in \mathbb{R}$. Verifying this rank condition assume that there exists a vector $v=\left[v_{1}, v_{2}\right]$ such that

$$
\left[v_{1}, v_{2}\right] \cdot\left\{\left[\begin{array}{cc}
s \cdot B-\left(I_{n}-A\right) & 0 \\
E & s \cdot I_{m}-\langle g\rangle
\end{array}\right] ;\left[\begin{array}{c}
-I_{n} \\
0
\end{array}\right]\right\}=[0,0]
$$

i.e. the rows of the matrix are dependent. By carrying out the multiplications we get the following system

$$
\begin{aligned}
v_{1} \cdot\left[s \cdot B-\left(I_{n}-A\right)\right]+v_{2} \cdot E & =0 \\
v_{2}\left(s \cdot I_{m}-\langle g\rangle\right) & =0 \\
-v_{1} & =0
\end{aligned}
$$

Substituting the third equation into the first, we obtain that $v_{1}=0$ and $v_{2}=0$ which proves the condition.

For a policy implication of this result, suppose that the government or a regulatory organization wants to regulate the stocks of renewable natural resources. For example, in the context of sustainable development to save the stocks, this can be done by controlling the level of the consumption rate. The slow-down of the exploitation of renewable resources will increase the possibilities of the next generations to get hold of natural resources. The assumption on the linear independence of the row vectors of input coefficients of resources can be held because of the non-substitutability of various natural resources.

\section{The examination of resources along the Bal- anced Growth Path}

The linear system in (3) is controllable in the usual mathematical sense. However, economics also requires the nonnegativity of the control and the state variables. In this section we will examine this issue for the case of a balanced growth path for both production and consumption. Fixing a given control (that is, for a given consumption), we examine the trajectories of system (1) and the effect of a balanced path on the use of the renewable environmental resources. 
We study the balanced growth solution of the system (1) under the assumption that both production and consumption increase at the same given growth rate $\alpha \geq 0$. That is, $x(t)=x_{0} e^{\alpha t}$ and $c(t)=c_{0} e^{\alpha t}$. Substituting these expressions in equation (1), yields that the following equality must hold:

$$
\left(I_{n}-A-\alpha B\right) x_{0}=c_{0} .
$$

This equation indicates that the output configuration $x_{0}$ corresponding to the balanced growth path, depends on both $\alpha$ and $c_{0}$. Define the marginal growth rate $\alpha_{0}$ such that the Frobenius root (or dominant eigenvalue) of the matrix $A+\alpha_{0} B$ equals one (see Schoonbeek [12]). The solution is given by

$$
x_{0}(\alpha)=\left(I_{n}-A-\alpha B\right)^{-1} c_{0}
$$

Next, we investigate the evolution of the stocks of renewable resources corresponding to the balanced growth path of system (3). Substituting $x(t)=x_{0} e^{\alpha t}$ in equation (2) and applying a simple procedure gives the following result for the stocks of resources:

$$
N(t)=e^{<g>t} N_{0}-\left(e^{<g>t}-e^{\alpha I_{m} t}\right) \cdot\left(<g>-\alpha I_{m}\right)^{-1} E x_{0}(\alpha)
$$

Theorem 2 For every index $i$ and $\alpha \leq g_{i}$, the stock of resources $N_{i}(t)$ remains nonnegative over the time horizon $t \in[0,+\infty)$.

In addition, for every index $i$ and for every fixed $t \in[0,+\infty)$ the stock $N_{i}(t)$ is monotone decreasing

(i) with respect to $\alpha$ on the interval $0 \leq \alpha<\alpha_{0}$ and

(ii) with respect to any nonnegative consumption vector $c_{0}$.

Proof. The first property can be verified easily by equation (9). The second property follows from examining the appropriate derivatives.

In economic terms, this theorem states that renewable resources will be not fully exhausted if the rate of growth is lower than the minimal rate of regeneration. In other case, i.e. growth rate is greater than the regeneration rate, the renewable resources can be considered, as a non-renewable resource. The environmental protection agencies must stimulate such an economic growth as not greater than the regeneration rate of natural regenerative resources. In a balanced growth economy the government and/or regulatory organisation have two economic indicators to control the exploitation of renewable natural resources: a reasonable growth rate, or proportion of the consumption level. The regulation of the growth rate has a direct effect on the exploitation of the natural resources. A reduction of the growth rate will decrease the exploitation of the resource levels. The influence of the consumption level is twofold: a proportional decrease of final demand for all sectors reduces the resource exploitation. In a 
non-proportional case, however, restricting the final demand in sectors with a high use of natural resources can reserve resources for sectors with lower use of natural resources. In this sense there is a potential trade-off between balanced growth rate and balanced consumption level. The consumption level can be increased with a lower growth rate to hold the available natural resources for future generations.

\section{A Numerical Example}

In order to illustrate the functioning of the proposed model, we take a simple case by aggregating the investigated economic system into three major sectors, assuming that each producing sector uses two types of resources. We set the parameters of the matrices of input coefficients, capital coefficients and resource coefficients as follows.

$$
A=\left[\begin{array}{lll}
0.1 & 0.3 & 0.2 \\
0.5 & 0.2 & 0.4 \\
0.2 & 0.4 & 0.5
\end{array}\right] \quad B=\left[\begin{array}{ccc}
0.01 & 0.03 & 0.02 \\
0.05 & 0.02 & 0.04 \\
0 & 0 & 0
\end{array}\right]
$$

and

$$
E=\left[\begin{array}{lll}
0.6 & 0.2 & 0.1 \\
0.4 & 0.5 & 0.3
\end{array}\right] \quad g=\left[\begin{array}{l}
0.2 \\
0.3
\end{array}\right]
$$

Using the results of Theorem 2, the marginal growth rate of the model is $\alpha_{0}=0.792$, but the minimal rate of regeneration is $\min _{1 \leq i \leq 2} g_{i}=0.2$. This means that a rational growth rate must be lower than this threshold. Let us assume next that the vectors $c_{0}$ of initial consumption levels and $N_{0}$ with the initial stock of exhaustible resources are

$$
c_{0}=\left[\begin{array}{l}
1 \\
3 \\
2
\end{array}\right] \quad \text { and } \quad N_{0}=\left[\begin{array}{c}
10,000 \\
15,000
\end{array}\right]
$$

Let us now investigate two cases. In the first case we assume that the growth rate is equal to 0.28 . For this growth rate the first renewable resource is actually a non-renewable resource, because the growth rate is greater than the rate of natural regeneration, $\alpha>g_{1}$. After some calculations it can be seen that the first resource lasts 34 years. Figures 1 and 2 show these resources. The second natural resource is a renewable resource, because the growth rate is smaller than the rate of natural regeneration, i.e. $\alpha<g_{2}$.

In the next example we assume that the growth rate is 0.1 , i.e. $\alpha=0.1$. In this example the growth rate is smaller than both of the rate of natural regeneration, i.e. $\alpha<g_{1}<g_{2}$, so for this economy the renewable resources will not be totally exhausted under this growth rate. 


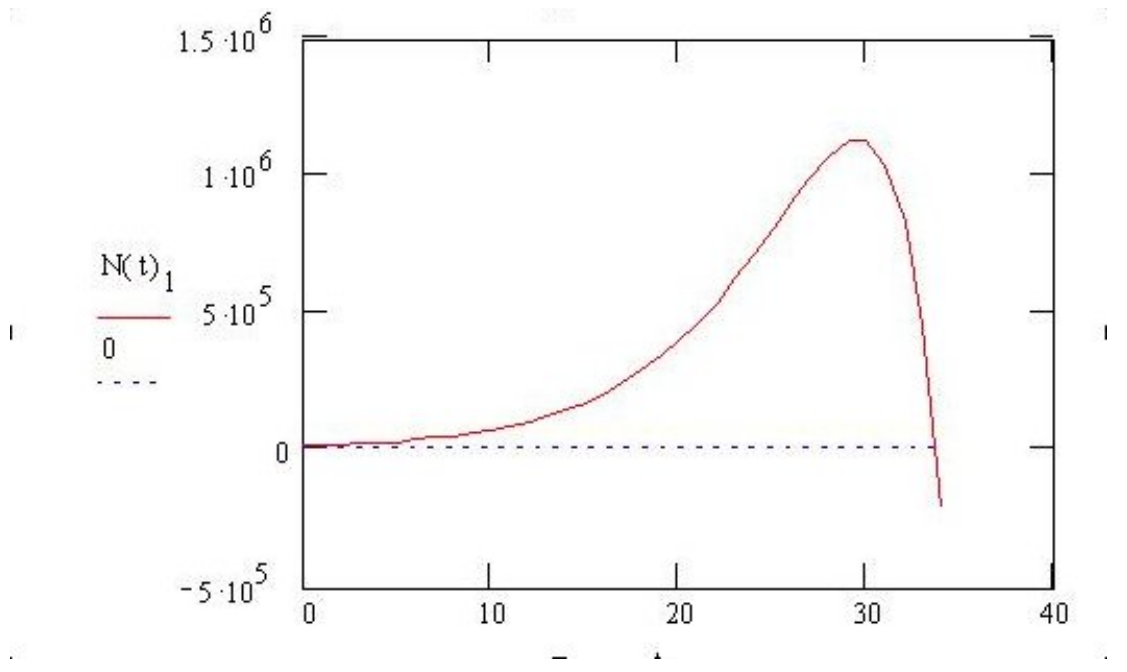

Figure 1: The stock level of the first natural resource for $\alpha=0.28$

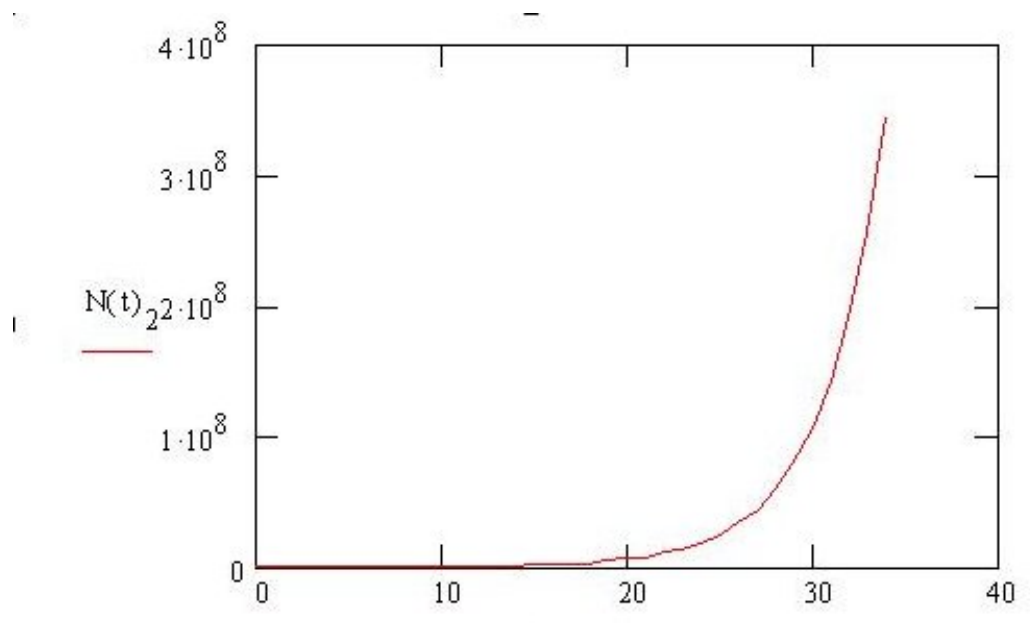

Figure 2: The stock level of the second natural resource for $\alpha=0.28$ 


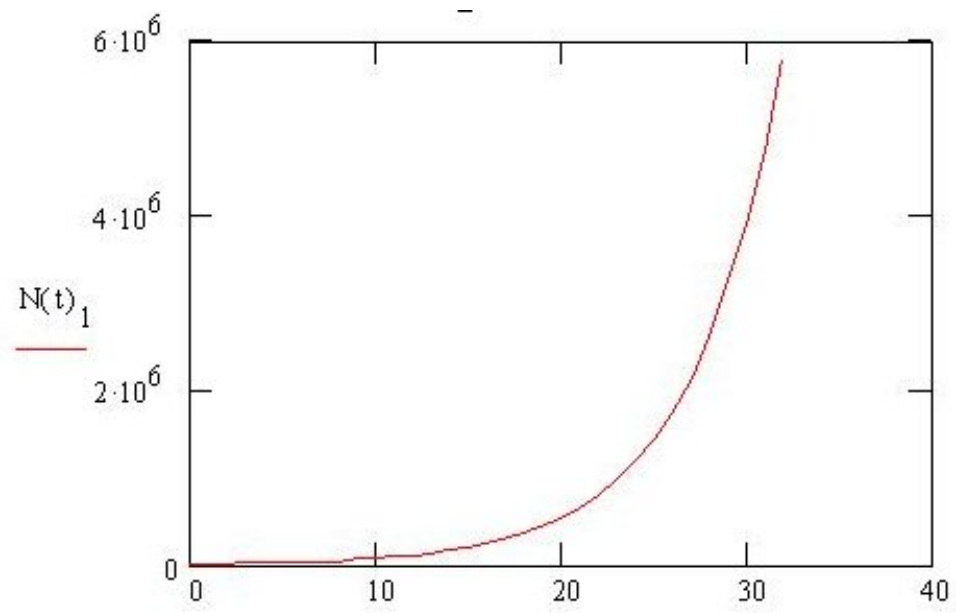

Figure 3: The stock level of the first natural resource for $\alpha=0.1$

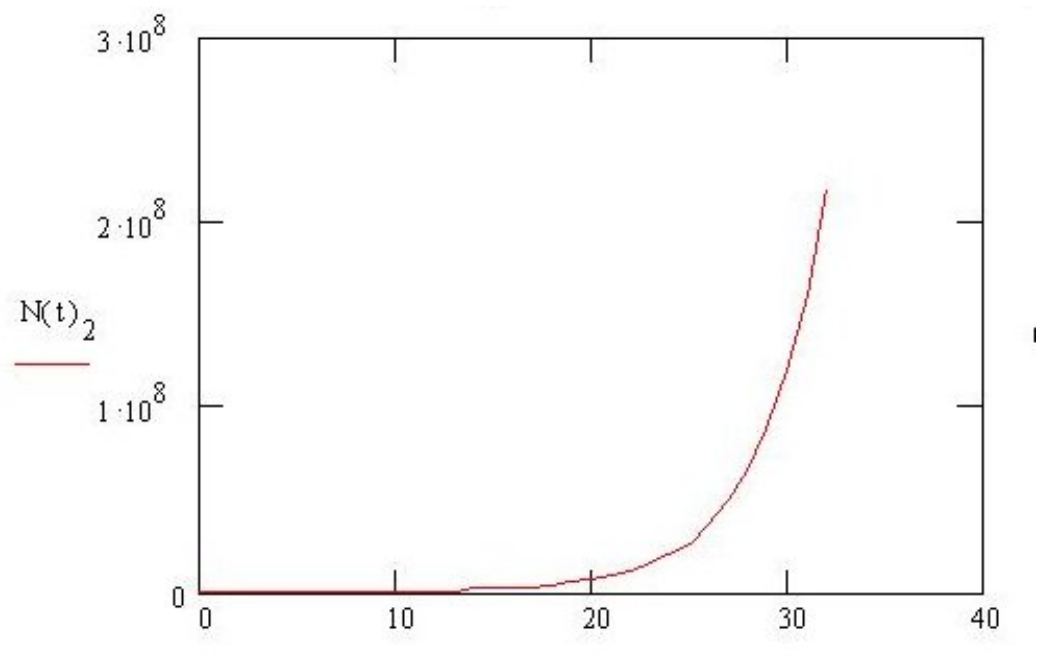

Figure 4: The stock level of the second natural resource for $\alpha=0.1$ 


\section{Conclusions and Further Research}

In this paper we have investigated a generalised dynamic Leontief model. The basic model was extended with regenerative resources. It was shown that this augmented model is controllable if the input matrix of resources has a full rank. In the second part of the paper we have examined the effect of the balanced growth path on the resource exploitation. It was shown that the stock of renewable resources lasts if the regeneration rates of natural resources are higher than the growth rate.

A topic for further research would be the effect of the balanced growth path on the quality of the renewable environmental resources. The question is how the use of the environmental resources (emission) will influence this balanced path if the emission level is limited by a legal environmental standard. A second possibility would be to extend the present model with the recycling of reusable materials. In this case the coefficients of the input matrix of resources will be reduced and the environmental resources will last longer. Such an investigation may be relevant in the context of sustainable development. Note that these investigations (as well as the model that we have used in this paper) ignore the influence of prices on the growth path. Considering the dual problem could shed some light on the issue of economic efficiency of production. Developing a new price system could control the production in an environmental-conscious way.

\section{REFERENCES}

[1] Aoki, M., Optimal Control and Systems Theory in Dynamic Economic Analysis, North-Holland, New York, Oxford, Amsterdam, 1976.

[2] Ayong Le Kama, A. D., Sustainable growth, renewable resources and pollution, J. Economic Dynamics \& Control, 25 (2001), pp. 1911-1918.

[3] Clark, V. W., Mathematical models in the economics of renewable resources, SIAM Review, 21 (1979), pp. 81-99.

[4] DAI, L., Singular Control Systems, Springer-Verlag, New York, Berlin, 1989.

[5] Dobos I., Floriska, A., A dynamic Leontief model with non-renewable resources, Economic Systems Research, 17 (2005), pp. 319-328.

[6] Dobos I., Floriska, A., The resource conservation effect of recycling in a dynamic Leontief model, Int. J. Production Economics, 108 (2007), pp. $334-340$.

[7] Eliasson, L., Turnovsky, S. J., Renewable resources in an endogenously growin economy: balanced growth and transitional dynamics, $J$. Environmental Economics and Management, 48 (2004), pp. 1018-1049. 
[8] Field, B. C., Environmental Economics: An Introduction, McGraw-Hill, New york, 1997.

[9] Gantmacher, F. R., Theory of Matrices, Chelsea, New York, 1959.

[10] Leontief, W. W., Input-Output Economics, Oxford Univesity Press, Oxford, New York, 1986.

[11] LI, C.-Z., LöFGREN, K.-L., Renewable resources and economic sustainability: a dynamic analysis with heterogeneous time preferences, J. Environmental Economics and Management, 40 (2000), pp. 236-250.

[12] Schoonbeek, L., The Size of the Balanced Growth Rate in the Dynamic Leontief Model, Economic Systems Research, 2 (1990), pp. 345-349.

[13] Valente, S., Sustainable development, renewable resources and technological progress, Environmental \&3 Resources Economics, 30 (2005), pp. $115-125$.

[14] WirL, F., Sustainable growth, renewable resources and pollution: thresholds and cycles, J. Economic Dynamics 83 Control, 28 (2001), pp. 11491157. 